\title{
Nursing Diagnoses of Patients With Neurological Disorders In Ward
}

\section{Suyanto}

Universitas Islam Sultan Agung

\section{Article Info}

\section{Article History: \\ Accepted Oct 9th 2018}

Key words:

Nursing diagnosis

Neurology disorder

\begin{tabular}{l} 
Abstract \\
\hline Neurological disorders consist of stroke, meningitis, neurosurgery. Stroke \\
is a condition where there is an attack on the blood vessels of the brain, \\
either in the form of a blocked or ruptured blood vessel. The role of nurses \\
as providers of nursing services is determined from the nursing diagnosis. \\
The study wants to find out the main nursing diagnoses that appear in \\
neurological disorders, especially stroke cases. Descriptive design was used \\
in this study with a sample of 30 cases of patients who experienced \\
neurological disorders using purposive sampling. There were 4 (four) main \\
diagnoses that emerged, namely physical mobility disorders as many as 22 \\
cases (73\%), risk of ineffective cerebral perfusion and nutrition deficit of \\
each of 19 cases (63.3\%), decreased intracranial adaptive capacity by 9 \\
cases (30\%). Nursing diagnosis in patients in the care ward is more \\
dominant in the rehabilitation phase. Perhaps more research about nursing \\
diagnosis of neurological disorder in emergency departement.
\end{tabular}

Abstract

\section{PENDAHULUAN}

Gangguan neurologi dapat disebabkan oleh infeksi, trauma, cancer, dan autoimun (Hickey, 2014). Setiap penyebab terjadinya gangguan neurologi memiliki tanda dan juga gejala yang spesifik. Salah satu contohnya adalah gangguan neurologi yang disebabkan oleh trauma. Jika seseorang mengalami trauma pada kepala maka pasien tersebut dapat terjadi peningkatan intra kranial, menurunnya tingkat kesadaran. Begitu juga kalau terjadi gangguan infeksi pada otak, maka pasien tersebut dapat mengalami kejang, penurunan kesadaran.

Peran perawat dalam melakukan perawatan pasien dengan gangguan neurologi baik yang disebabkan oleh infeksi, trauma, cancer ataupun autoimun berfokus pada kebutuhan dasar yang terganggu (Doengoes, 2013). Kebutuhan dasar yang terganggu inilah yang akan dijadikan dasar oleh perawat untuk dilakukan pengkajian spesifik. Pengkajian yang dilakukan akan didapatkan data yang selanjutnya akan disusun dan ditentukan diagnosis keperawatan yang tepat.

Diagnostik keperawatan merupakan suatu penilaian klinis mengenai respon pasien terhadap masalah kesehatan atau proses kehidupan yang dialaminya baik yang berlangsung aktual maupun potensial (Ackley et al, 2017). Diagnosis keperawatan bertujuan untuk mengidentifikasi respon klien individu, keluarga dan komunitas

\footnotetext{
Corresponding author:

Suyanto 
terhadap situasi yang berkaitan dengan kesetahatan. Masalah kesehatan mengacu kepada respons klien terhadap kondisi sehat sakit. Masalah kesehatan tersebut dapat diatasi atau diubah dengan intervensi keperawatan (Christensen\&Kenney, 2009).

Fokus pengkajian keperawatan pada pasien dengan gangguan neurologi khususnya pada pasien stroke sangat bergantung pada fase serangan stroke. Pasien yang telah melewati fase akut atau sedang melewati fase akut akan dirawat dibangsal. Berdasarkan hasil studi pendahuluan didapatkan data bahwa sangat beragamnya kebutuhan dasar yang terganggu akan berbanding lurus dengan pengkajian dan diagnosis keperawatan yang akan muncul. Untuk itu penelitian ini bertujuan untuk memberikan gambaran diagnosis utama yang sering muncul pada pasien-pasien dengan gangguan neurologi di bangsal perawatan.

\section{METODE}

Desain penelitian ini adalah deskriptif study dengan jumlah responden sebanyak 30 . Adapun kriteria inklusi pada penelitian ini adalah seluruh pasien dengan gangguan neurologis yang dirawat di bangsal. Teknik pengambilan sampel menggunakan purposive sampling. Pengambilan data dilakukan pada bulan Mei 2017. Uji analisis distribusi frekuensi digunakan untuk melihat jumlah dan prosentase diagnosis keperawatan yang muncul.

\section{HASIL}

Tabel 1

Karakteristik responden berdasarkan 4 (empat) besar diagnosis medis $\mathrm{n}=30$ reponden

\begin{tabular}{cccc}
\hline No & $\begin{array}{c}\text { Diagnosis } \\
\text { medis }\end{array}$ & Jumlah & $\begin{array}{c}\text { Persentase } \\
\text { (\%) }\end{array}$ \\
\hline 1 & $\begin{array}{c}\text { Stroke } \\
\text { Hemoragi }\end{array}$ & 12 & 40 \\
\hline 2 & $\begin{array}{c}\text { Stroke } \\
\text { Iskemik }\end{array}$ & 11 & 36.7 \\
\hline 3 & Trauma & 3 & 10 \\
\hline 4 & $\begin{array}{c}\text { Infeksi intra } \\
\text { kranial }\end{array}$ & 2 & 6.7 \\
\hline
\end{tabular}

Tabel 1 didapatkan data bahwa ada 4 besar kasus pada penelitian ini yaitu stroke hemoragi dengan jumlah 12 orang (40\%), stroke iskemik sejumlah 11 orang $(36,7 \%)$, trauma kepala sebanyak 3 orang (10\%), dan infeksi intra kranial sejumlah 2 orang $(6,7 \%)$.

Tabel 2

Karakteristik responden berdasarkan diagnosis keperawatan pasien gangguan neurologis di bangsal perawatan $n=30$ responden

\begin{tabular}{llcl}
\hline No & $\begin{array}{l}\text { Diagnosis } \\
\text { Keperawatan }\end{array}$ & Jumlah & (\%) \\
\hline 1 & Gangguan mobilitas fisik & 22 & 73 \\
\hline 2 & $\begin{array}{l}\text { Resiko perfusi srebral } \\
\text { tidak efektif }\end{array}$ & 19 & 63.3 \\
\hline 3 & Defisit nutrisi & 19 & 63.3 \\
\hline 4 & $\begin{array}{l}\text { Penurunan kapasitas } \\
\text { adaptif intrakranial }\end{array}$ & 9 & 30 \\
\hline
\end{tabular}

Diagnosis keperawatan yang paling sering dijumpai pada pasien gangguan neurologis adalah gangguan mobilitas fisik dengan 22 responden (73\%). Kemudian diikuti oleh diagnosis resiko perfusi serebral tidak efektif dan defisit nutrisi masing-masing 19 responden (63.3\%). Kemudian diagnosis yang terakhir adalah penurunan kapasitas adaptif intrakranial sebanyak 9 responden (30\%).

\section{PEMBAHASAN}

1. Gangguan mobilitas fisik

Gangguan mobilitas fisik merupakan suatu keadaan dimana terjadi keterbatasan dalam gerakan fisik dari satu atau lebih ekstremitas secara mandiri (Ackley et al, 2017). Secara umum penyebab atau etiologi terjadinya gangguan mobilitas fisik adalah penurunan kekuatan otot, penurunan massa otot,gangguan neuromuskular dan gangguan muskuloskeletal (Ackley et al, 2017). Instumen yang digunakan dalam mengkaji masalah gangguan mobilitas fisik adalah dengan mengukur kekuatan otot pasien. hasil dari pengkajian 
kekuatan otot dimulai dari angka 0 sampai angka 5. Hasil penelitian lain didapatkan data bahwa 90\% diagnosis keperawatan yang muncul pada pasien stroke adalah gangguan mobilitas fisik ( Costa et al, 2010). Gangguan mobilitas fisik terutama pada gangguan neurologi yang disebabkan oleh adanya infark atau perdarahan pada otak (Hickey, 2014). Diagnosis gangguan mobilitas fisik merupakan efek dari adanya kerusakan pada syaraf pusat terutama pada bagian korteks serebri. Hasil penelitian lainnya menyatakan bahwa $50 \%$ diagnosis keperawatan pada pasien stroke adalah gangguan mobilitas fisik, risiko jatuh, dan gangguan kemampuan berpindah (Oliveira et al, 2012). Gangguan mobilitas fisik merupakan masalah keperawatan yang sering muncul pada pasien stroke. Akibat dari gangguan mobilitas fisik ini, seorang pasien dapat beresiko jatuh sehingga pencegahan terjadinya kejadian jatuh dan penangan dalam meningkatkan kekuatan otot penderita gangguan neurologis sangat besar pengaruhnya terhadap aktivitas fisik pasien.

\section{Risiko perfusi serebral tidak efektif}

Diagnosis keperawatan risiko perfusi jaringan serebral tidak efektif merupakan kondisi dimana berisiko mengalami penurunan sirkulasi darah ke otak. Faktor resiko yang memungkinkan terjadinya diagnosis tersebut adalah aterosklerosis aorta, masa protrombin tidak normal, fibrilasi atrium, aneurisma serebri, embolisme (Ackley,2017).

\section{Defisit nutrisi}

Diagnosis defisit nutrisi yang
dihubungkan dengan gangguan
menelan, penurunan kesadaran
(Hickey, 2014). Gangguan menelan atau
disfagia merupakan salah satu masalah
yang berbahaya pada stroke akut (

Marian et al, 2017). Hasil penelitian sebelumnya yang dilakukan oleh Abubakar \& Jamoh (2017) dan Kwak et al (2018) dinyatakan bahwa kejadian disfagia pada fase akut stroke sebanyak 25\%-34,4\%. Hal ini didukung oleh penelitian lain bahwa kejadian disfagia paling tinggi pada fase akut stroke. Hal ini sangat erat terkait dengan lokasi lesi pada otak. Hasil penelitian sebelumnya menyatakan bahwa kejadian disfagia sangat terkait dengan stroke. Pasien dengan lesi pada sirkulasi serebral bagian anterior memiliki insidensi disfagia yang tinggi dalam minggu pertama setelah kejadian. Ketika diperiksa lebih dekat, $75 \%$ dari pasien ini mengalami disfagia dua hari setelah stroke dan 90\% dari keadaan tersebut tetap mengalami disfagia setelah 1 minggu setelah menderita stroke. Infark yang melibatkan arteri serebral bagian anterior terutama bertanggung jawab untuk disfagia, karena mereka mempengaruhi area penting yang terlibat dalam mengontrol fungsi menelan ( Otto et al, 2016). Pasien stroke dengan lesi pada hemisfer kanan memiliki kejadian disfagia yang jauh lebih tinggi dibandingkan dengan pasien stroke mengalami lesi pada hemisfer kirinya.Munculnya lesi pada korteks sensorik primer yang lebih tinggi pada pasien disfagia dapat dikaitkan dengan peran input sensorik dalam mengendalikan gerakan menelan (Dehaghani et al, 2016).

Selama menelan, gerakan tulang hyoid penting untuk membuka sfingter esofagus dengan menyebabkan epiglotis memiringkan. Penurunan patologis atau keterlambatan dalam gerakan tulang hyoid adalah faktor risiko utama untuk aspirasi (Ishida et al, 2002). Peningkatan laring dan gerakan tulang hyoid dapat diperkirakan secara kasar menggunakan metode palpasi subjektif dan non-kuantitatif. Untuk menilai kemampuan menelan termasuk 
gerakan tulang hyoid, mayoritas penelitian sebelumnya telah menggunakan studi menelan videofluoroscopic (VFSS). Baru-baru ini, ultrasonografi (US) telah digunakan untuk menilai disfagia, karena pendekatan ini berbiaya rendah, tidak melibatkan radiasi, dan sangat mudah diakses. Kemampuannya untuk mengevaluasi struktur dinamis menunjukkan bahwa elevasi laring dapat diukur dengan mudah dengan identifikasi gerakan tulang hyoid, yang merupakan proses paling penting dalam menelan dan faktor yang menentukan untuk aspirasi dan penetrasi. Pasien yang mengalami disfagia juga beresiko mengalami aspirasi. Berdasarkan hasil penelitian didapatkan bahwa seluruh pasien yang mengalami disfagia dilakukan pemasangan Naso gastric tube (NGT). Berdasarkan hasil penelitian yang dilakukan oleh Kwak et al (2018) bahwa NGT mengganggu pergerakan tulang hyoid selama menelan $1 \mathrm{~mL}$ air pada pasien stroke dan dipulihkan setelah melepas NGT. Dalam kasus pasien stroke yang membutuhkan tabung makan untuk waktu yang lama, efek buruk NGT pada fungsi menelan harus dipertimbangkan.

\section{Penurunan kapasitas adaptif intrakranial}

$\begin{array}{lcr}\text { Diagnosis } & \text { keperawatan } & \text { penurunan } \\ \text { kapasitas } & \text { adaptif } & \text { intrakranial } \\ \text { merupakan } & \text { gangguan } & \text { mekanisme } \\ \text { dinamika } & \text { intrakranial } & \text { dalam } \\ \text { melakukan } & \text { kompensasi } & \text { terhadap }\end{array}$
stimulus yang dapat menurunkan kapasistas intrakranial (Ackley et al, 2017). Etiologi yang dapat memunculkan diagnosis ini adalah lesi pada otak, edema serebral, peningkatan tekanan vena, obstruksi aliran liquor cerebro spinal (LCS) serta gangguan metabolik. Gejala dan tanda yang dapat dijadikan acuan dalam menegakkan diagnosis ini adalah sakit kepala, cushing sign yang terdiri dari tekanan darah meningkat, bradikardia, pola nafas ireguler. Kemudian terjadi penurunan tingkat kesadaran baik secara kualitatif maupun kuantitatif, respon pupil tidak sama antara kanan dan kiri atau melambat, serta terganggunya refleks neurologis (Ackley et al, 2017). Penurunan tingkat kesadaran secara kualitatif secara hierarki dimulai dari kesadaran penuh, bingung, letargi, obtundasi, stupor dan koma. Sedangkan untuk tingkat kesadaran secara kuantitatif dapat digunakan glasgow coma sclae (GCS) (Hickey, 2014).

Diagnosis keperawatan lainnya yang dapat muncul pada gangguan neurologis adalah hambatan komunikasi verbal. Menurut Chaves et al (2013) menyatakan bahwa 37,5\% pasien stroke mengalami diagnosis keperawatan gangguan komunikasi verbal. Keterbatasan dalam penelitian ini adalah jumlah sampel yang tidak homogen pada kasus tertentu dan cakupan tempat penelitian. Untuk penelitian selanjutnya diharapkan difokuskan pada satu kasus dengan tempat penelitian yang lebih luas sehingga hasil yang didapatkan akan jauh lebih baik.

Diagnosis keperawatan merupakan salah satu dari rangkaian kegiatan asuhan keperawatan yang dilakukan oleh perawat. Khususnya dalam perawatan pasien dengan gangguan neurologis, seorang perawat dapat melakukan tindakan keperawatan yang sesuai dengan diagnosis keperawatannya. Diagnosis yang paling sering ditegakkan dalam perawatan pasien gangguan neurologis adalah gangguan mobilitas fisik. Hal ini sangat terkait dengan fungsi syaraf khususnya pada bagian otak. Untuk itu perlu adanya pemahaman yang lebih komprehensif yang dilakukan oleh perawat sehingga akan meningkatkan kualitas layanan keperawatan. 


\section{REFERENSI}

Abubakar, S.A. \& Jamoh, B.Y. (2017). Dysphagia following acute stroke and its effect on shortterm outcome. Nigerian Postgraduate Medical Journal;24(3):182-186. doi: 10.4103/npmj.npmj_96_17.

Ackley et al. (2017). Nursing diagnosis handbook, an evidence based guide to planning care.11th Ed.St.Loius: Elsevier

Chaves, D.B.R., Costa, A.G.S., Oliveira, A.R.S., Silva, V.M., Araújo, T.L.,\& Lopes, M.V.O. (2013). Comunicação verbal prejudicada - investigação no período pós-acidente vascular encefálico. Rev RENE;14(5):877-85

Costa, A.G.S., Oliveira, A.R.S., Alves, F.E.C., Chaves, D.B.R., Moreira, R.P., \& Araujo, T.L. (2010). Nursing diagnosis: impaired physical mobility in patients with stroke. Rev Esc Enferm USP. 44(3):753-8.

Christensen, P. J., \& Kenney, J. W. (2009). Proses Keperawatan Aplikasi Model Konseptual. (Y. Yuningsih \& Yasmin Asih, Eds.1). Jakarta: EGC.

Dehaghani SE, Yadegari F, Asgari A, Chitsaz A, Karami M. (2016). Brain regions involved in swallowing: Evidence from stroke patients in a cross-sectional study. Journal of Research in Medical Science;14;21:45.

Dongoes, M.E., Moorhouse, M.F., \& Murr, A.C. (2013). Nursing diagnosis manual plannning, individuliting and documentating clienr care. 4th Ed. Philadelphia: F.A Davis Company
Hickey, J. V. (2014). The Clinical Practice of Neurological and Neurosurgical Nursing (7th ed.). Philadelphia: Lippincot Williams \& Walkins.

Kwak et al.(2018). Influence of Nasogastric Tubes on Swallowing in Stroke Patients: Measuring Hyoid Bone Movement With Ultrasonography. Annals of Rehabilitation Medicine; 42(4): 551-559. doi: 10.5535/arm.2018.42.4.551

Ishida, R., Palmer, J,B.,\& Hiiemae, K.M. (2002). Hyoid motion during swallowing: factors affecting forward and upward displacement. Dysphagia;17:262-72.

Marian et al. (2017). Measurement of Oxygen Desaturation Is Not Useful for the Detection of Aspiration in Dysphagic Stroke Patients. Cerebrovasc Dis Extra;7(1):44-50. doi: $10.1159 / 000453083$.

Oliveira, A.R.S., Costa, A.G.S., Moreira, R.P., Cavalcante, T.F.,\& Araujo, T.L. (2012). Diagnósticos de enfermagem da classe atividade/exercício em pacientes com acidente vascular ce- rebral. Rev Enferm UERJ;20(2):221-8.

Otto, D.M., Ribeiro, M.C, Barea, L.M., Mancopes, R., \& Almeida, S.T. (2016). Association between neurological injury and the severity of oropharyngeal dysphagia after stroke. Codas;28(6):724-729. doi: 10.1590/23171782/20162015139. 